\title{
Sex Education on Islamic Religious Learning To Prevent and Correct Average Behavior In High Schools In Cirebon
}

\author{
Sri Maryati, Muhibbinsyah, Aan Hasanah, Erihadiana \\ Sunan Gunung Djati State Islamic University Bandung, Indonesia \\ Sunan Gunung Djati State Islamic University Bandung, Indonesia \\ Sunan Gunung Djati State Islamic University Bandung, Indonesia \\ Sunan Gunung Djati State Islamic University Bandung, Indonesia \\ Email: srimaryati@umc.ac.id, muhibbinsyah@uinsgd.ac.id, aanhasanah@uinsgd.ac.id, \\ erihadiana@uinsgd.ac.id
}

\begin{tabular}{|c|c|}
\hline ARTICLE INFO & ABSTRACT \\
\hline $\begin{array}{l}\text { Received } \\
23 \text { Juny } 2021 \\
\text { Revision } \\
1 \text { July } 2021 \\
\text { Approved } \\
10 \text { July } 2021 \\
\text { Keywords: } \\
\text { sex education } \\
\text { islamic religious } \\
\text { learning } \\
\text { deviation }\end{array}$ & $\begin{array}{l}\text { This study aims to describe sex education in Islamic religious learning } \\
\text { to prevent and overcome deviant behavior at SMAN Cirebon City. This } \\
\text { study uses a qualitative approach with a descriptive method. Data } \\
\text { collection techniques through interviews, observation and } \\
\text { documentation. Data analysis techniques using data analysis } \\
\text { techniques consisting of data reduction, data presentation, and } \\
\text { conclusions. The results of this study indicate that: in general, } \\
\text { students at SMAN in Cirebon City do not all have sufficient knowledge } \\
\text { about sexuality. In addition, many of the students still consider it } \\
\text { taboo to talk about sexual education. It is a separate task for } \\
\text { educators to explain the concept of sexual education. Do not let } \\
\text { students actually get information from sources that cannot be } \\
\text { accounted for. In overcoming sexual behavior deviations among } \\
\text { students at SMAN in Cirebon City, schools play an important role. } \\
\text { Some of the roles that schools play in the process of overcoming } \\
\text { sexual deviance include (1) providing sex education, (2) providing } \\
\text { religious moral education, (3) controlling discipline, (4) becoming } \\
\text { consultants and friends for their students. }\end{array}$ \\
\hline
\end{tabular}

\section{INTRODUCTION}

The emergence of free sex behavior today among teenagers, can not be separated from the rapid development of science and technology (Science and Technology) as a result of globalization and westernization. With the advancement of science and technology, it is easier for someone, including teenagers, to access information, one of which is information about sex. As a result, many teenagers commit sexual behavior deviations such as pre-marital sex or sexual crimes committed by teenagers. This is due to the lack of understanding about proper sex and moral education among teenagers, so that they are easily carried away by the current of globalization.

In addition, adolescence is a phase in which humans are experiencing a transition from childhood to adulthood. During this transition period, a teenager experiences many changes, both physically and psychologically. This results in an increase in adolescent attention to sexual life during the pubertal period. Physically, the maturity of the sexual organs and hormonal changes lead to the emergence of sexual urges in adolescents. This sexual drive is very high even higher than the adult sex drive. As a young person who has not had sexual
How to cite:

E-ISSN:

Published by:
Maryati, Sri, Muhibbinsyah, Aan Hasanah, Erihadiana (2021) Sex Education on Islamic Religious Learning To Prevent and Correct Average Behavior In High Schools In Cirebon. Jurnal of Social Science 2(4). https://jsss.co.id/index.php/jsss/article/view/185 2721-5202 Ridwan Institute 
experience, this creates physical and psychological tension ketegangan (Samsunuwiyata Mar'at, 2008).

To release this sexual tension, adolescents try to express their sexual urges in various forms of sexual behavior, ranging from dating, dating, making out, to having sexual contact. Of the many sexual behaviors that teenagers do, one of the most common is masturbation. Like Researchers find data from a site, that based on research results Taufik (2018) about the sexual behavior of high school adolescents in Surakarta with a sample size of 1,250 people from 10 high schools in Surakarta, consisting of 611 boys and 639 girls, stated that $10.53 \%$ of adolescents had kissed on the lips, 5.6\% had kissed in , $4.23 \%$ masturbate or masturbate and $3.09 \%$ have sexual intercourse (Taufik, 2018). This phenomenon is clearly very worrying parents and society. Because although sexuality is a normal part of development, sexual behavior is accompanied by risks that are not only borne by adolescents themselves, but also by parents and society. (Samsunuwiyata Mar'at, 2008).

The reason that is used as the basis for conducting Sex Education is the many cases of Unwanted Pregnancy (KTD), Abortion and giving birth at a young age. Because pregnancy, abortion and childbirth at a young age have a high risk (unhealthy or result in death), it needs to be prevented. The way to prevent this is to provide information to train and educate them, so Sex Education was chosen to increase adolescent knowledge about sexual problems in order to avoid deviations in sexual behavior. However, the current reality is that sex education has not been implemented properly and appropriately. The assumption that sex is still a taboo in society is still an obstacle to the implementation of Sex Education in accordance with the times and needs of today's youth. As a result, the massive and ubiquitous adolescent free sex behavior is now at a dangerous level.

According to data obtained from the West Java Provincial Health Office through the Provincial AIDS Commission (KPAP) of West Java, that up to 2017, the number of HIV cases was 5816 cases, the risk of transmission is through sexual intercourse, both heterosexual and homosexual, injecting drug users (injecting drug users). ), mother- to-child transmission and other unknown risks. Of course, this number of cases is likened to an iceberg phenomenon, that is, only the surface appears small, even though the actual cases are estimated to be much larger. Given that HIV cases can only be found by means of a blood test or often called Voluntary Counseling and Testing (KTS), this requires awareness for people who have done risky behavior to routinely every 3 months to check their HIV status (West Java Provincial Health Office).

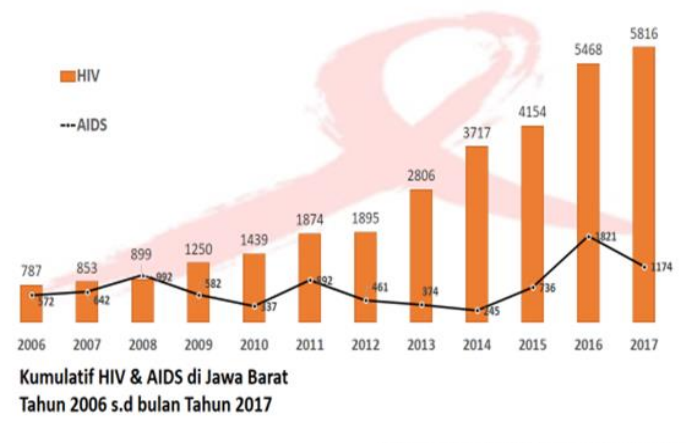

\section{Figure 1 \\ HIV \& AIDS Cumulative Chart in West java}

From these various studies, it can be seen that the source that makes free sex rampant among teenagers is due to the absence of applied politeness norms. For example, such as the association between the opposite sex, this simple thing has a lot of wisdom and benefits, because if it can be applied properly it will become a bulwark for adultery and can prevent deviations in sexual behavior among teenagers. Islam forbids to channel his sexual desires with disgraceful acts. Furthermore, to have legal sexual intercourse, a Muslim must be in a marriage bond. Therefore, it is important to have sex education in accordance with Islamic teachings because Islam is a religion that teaches politeness in learning any knowledge, especially on matters related to sexuality. The amount of information about sexuality that is received by Muslim youth is what it is, thus encouraging the Islamic world to formulate sex education in accordance with Islamic provisions. Thus, it is hoped that adolescents will be able to distinguish clearly and firmly, 
which sex education includes Islamic values with sex education in general and sometimes tends to deny the rules of politeness that exist in the values of Islamic teachings.

However, parents, the education system and society tend to ignore the need to educate teenagers about sex in the right way (Wuryani, 2008). Many Muslim parents prohibit their children from asking questions about sex, so as a result of this prohibition, children think and their curiosity is aroused. Even though there is no doubt that prohibiting mumayiz's child from asking questions about sex will make him more curious to solve the problem. However, something vague will not stop the child from continuing to find out even though it is prohibited, humiliated, looked down upon, and reviled (Madani, 2003).

When an individual's curiosity is not satisfied, then he will look for a way that is not prescribed by religion just to find the secrets of sexual life. After a child enters puberty and finds a phenomenon that his parents have not prepared to deal with with adequate ability, then it will cause him to fall into various influences that will lead him to sexual deviation. (Madani, 2003).

Next to parents, school is the second place for sex education. As we know, school is a place where children study knowledge that will be useful for themselves in the future. At school, students are faced with teachers who teach various kinds of knowledge. Children's education, as has been the case until now, is entrusted to teachers in schools, as well as sex education (Wuryani, 2008).

The sex education curriculum, as quoted in Kompas January 2016 by Sri Esti Wuryani $D$, was planned partly because of the increasing number of unwanted pregnancies, which made sex education necessary in schools and this was anticipated by the world of education.

According to the Director of Primary and Secondary Education of the Ministry of Education and Culture, Hamid Muhammad quoted by CNN Indonesia in 2016, the 2013 curriculum (K-13) for Junior High School (SMP) and High School (SMA) levels has explicitly implemented Sex Education. the hours of Islamic Religious Education subjects in the 2013 curriculum were also added to three hours of lessons per week. However, the level of deviation and sexual behavior among school-level students is still high.

In this study the researchers took the subject of Islamic Religious Education (PAI) as a sample because Islamic Religious Education (PAI) learning includes materials related to sex education, such as morals and fiqh, especially in class X about taharah and class XII even semester. about Munakahat. However, the implementation of this learning is not paid attention, especially in public schools that do not have a religious basis. This is evident even though the lesson hours for Islamic Religious Education (PAI) subjects are increased (based on the 2013 Curriculum), but the rate of sexual behavior deviations and juvenile delinquency in public schools or high school / level in particular has also increased. This can be caused by several factors, one of which is the lack of precise methods or learning models used by a teacher in the classroom in delivering material related to sex education.

Based on initial observations through observations and interviews conducted on several high school students throughout the city of Cirebon as follows: the object of research, there are problems regarding the daily moral behavior of students. For example, there are students who are already dating, kissing, promiscuous with fellow friends, having abortions, and even often in the teaching and learning process using cellphones by browsing pornographic sites (Interview with several students in high school in Cirebon City, Monday 9 february 2021).

Then based on the information the author got from the AIDS Commission (KPA) Cirebon City stated that from year to year the discovery of HIV cases in the city of Cirebon was mostly found through sexual intercourse either through heterosexual or homosexual.

For more details, cumulative HIV-AIDS case data until 2018 in Cirebon City can be seen in the following explanation: 
Table 1

Countermeasures Commission AIDS Cirebon City

\begin{tabular}{ccccc}
\hline Year & HIV & AIDS & Total & Died \\
\hline 2006 & 4 & 2 & 6 & 9 \\
\hline 2007 & 38 & 1 & 39 & 10 \\
\hline 2008 & 28 & 12 & 40 & 9 \\
\hline 2009 & 10 & 10 & 20 & 2 \\
\hline 2010 & 36 & 6 & 42 & 3 \\
\hline 2011 & 32 & 3 & 35 & 4 \\
\hline 2012 & 28 & 0 & 28 & 5 \\
\hline 2013 & 41 & 12 & 53 & 6 \\
\hline 2014 & 41 & 13 & 54 & 6 \\
\hline 2015 & 43 & 0 & 43 & 0 \\
\hline 2016 & 37 & 0 & 37 & 0 \\
\hline 2017 & 42 & 0 & 42 & 13 \\
\hline amount & 380 & 59 & 439 & 67 \\
\hline
\end{tabular}

Source: Cirebon City AIDS Commission, 2017

The trend of the above phenomenon shows that adolescent sexual behavior contributes to the number of cases of HIV transmission. Moreover, the risk of transmission through sexual intercourse. Of course, this is greatly influenced by the establishment of adolescents in understanding Islam as a foundation for behavior and social relations, so it needs to be sharpened again related to Islamic Religious Education learning so that it is in line with the goals of education itself As reflected in the goals of National education as stated in the Law of the Republic of Indonesia No. 20 of 2003 concerning the National Education System (SISDIKNAS) that:

"National education aims to develop the potential of students so that they become human beings who believe and are devoted to God Almighty, have noble character, are healthy, knowledgeable, capable, creative, independent and become democratic and responsible citizens" (Law No. 2005, 2008).

Meanwhile, according to the Cirebon City Regional Regulation (PERDA) number 3 of 2015 concerning the Prevention and Control of Human Immunodeficiency Virus and Acquired Immune Deficiency Syndrome (HIV and AIDS). Which aims to regulate the roles, functions and responsibilities between the City Government, the community and the business world through partnerships as an effort to prevent and control HIV and AIDS in the City of Cirebon through the following activities:

a. implementation of HIV counseling and testing.

b. for couples who will carry out marriage are recommended to do HIV and AIDS counseling konseling.

c. reducing the adverse effects of injecting drug use.

d. obliged to report narcotics addicts; and

e. care, support and treatment (PDP) for PLWHA.

The Human Immunodeficiency Virus and Acquired Immune Deficiency Syndrome (HIV and AIDS) Prevention and Control Program, according to one of the high school principals in the city of Cirebon, stated that :

"The implementation of HIV-AIDS prevention in schools through internalization of Islamic values in activities in learning or outside of learning has often been instilled, which aims to realize Islamic education, namely forming human beings and shaping the character of all school members to have noble character through the program (Interview with Principal on January 23, 2021)."

From the description above, the researcher is very concerned about the development of students and the phenomena of sexual harassment and deviance that occur among students. As part of the academic community, the author feels the need to conduct research on sex education in schools, 
especially high schools (SMA) whose students are teenagers who are going through puberty.

This is what underlies the author to find a description of how sex education in Islamic learning to prevent and overcome deviant behavior in SMA-SMA in Cirebon City, especially in SMAN 1, SMAN 7 and SMAN 8 Cirebon City as the locus in this study.

\section{METHOD}

This research approach includes qualitative research. Because this research is intended to produce descriptive data in the form of exposure or description of sex education in Islamic religious learning to prevent and overcome deviant behavior in SMA-SMA in Cirebon City, especially in SMAN 1, SMAN 7 and SMAN 8 Cirebon City as the locus in the study. this. In addition to descriptive data, this research also uses a qualitative descriptive method, as stated by Sugiono, that descriptive qualitative research method is a research method used to examine the condition of natural objects, where the researcher is the key instrument, this research places the researcher as a research instrument to collect data, either through interview observations, attitude scales and documentation, while The data analysis technique uses data display, data reduction and data conclusion.

\section{RESULTS AND DISCUSSION}

To find out sex education in Islamic religious learning in preventing and overcoming deviant behavior in SMA-SMA in Cirebon City, especially in SMAN 1, SMAN 7 and SMAN 8 Cirebon City, the researchers described the findings through structured, unstructured interviews and added questions. supporting informants who are relevant and in direct contact with school principals, teachers and students, are:

\section{Knowledge of Sexuality in High School Students in Cirebon City}

In general, students in SMA-SMA in Cirebon City have knowledge about sexuality. Most of the students who were respondents (80 children or $87 \%$ ) admitted that they had received information about sex. However, the sources vary so that the answer model also varies.
Based on the results of the analysis of the data that the researchers obtained, it is known that most of the students in high schools throughout the city of Cirebon (35 children or $44 \%$ of the total number of children who claimed to have received information about sex education) received information about sexuality from friends. In addition, 16 children (20\%) received information from psychologists, 12 children (15\%) received information from teachers and socialization held by schools, in addition to receiving information from media such as television and magazines. The interesting thing is, among the respondents, only 1 child claimed to have received information about sexuality from their parents. This is certainly concerning because friends and magazines usually provide inaccurate information, highlighting the hedonic side more than the moral and ethical side. In addition, sexuality information from friends and magazines is usually not viewed from various aspects as a whole. From the results of the study, it was also found that this problem is still considered taboo so that not many parents provide explanations for their children.

On average, students in high schools in Cirebon City experienced wet dreams for the first time at the age of 10-15 years, namely 1 respondent at the age of 10 years, 2 respondents at the age of 11 years, 5 respondents at the age of 12 years, 3 respondents at the age of 13 years, 6 respondents at the age of 14 years, and 10 respondents at the age of 15 years. Meanwhile, 8 respondents answered that they forgot/don't remember the exact year they had a wet dream for the first time. Meanwhile for women, experiencing their first menstruation between the ages of 10-15 years, namely 3 respondents at the age of 10 years, 14 respondents at the age of 11 years, 14 respondents at the age of 12 years, 23 respondents at the age of 13 years, 6 respondents at the age of 15 years. In addition, 1 respondent answered that he had his first menstruation at the age of 16 years, 2 respondents answered that he forgot.

The percentage of students in high schools throughout the city of Cirebon 
who claimed not to know the consequences of premarital sex was quite large. 30 female respondents and 16 male respondents admitted that they did not know the consequences of premarital sex. This shows that $50 \%$ of the respondents are aware of the consequences of premarital sex. From $50 \%$ of respondents who claimed to know the consequences of premarital sex, the answers also varied. 20 female respondents and 10 male respondents answered that pregnancy was the result of premarital sex. The rest of the respondents had various answers, ranging from being infected with sexually transmitted diseases, embarrassing the family, a bleak future, and so on. When asked a question about how to prevent pregnancy, most (17 male respondents and 37 female respondents) answered no/don't know yet. A total of 8 male respondents and 16 female respondents answered how to prevent pregnancy, namely by not having sex. Only 6 male respondents and 3 female respondents answered using a safety device (condom) or birth control pills/injections. In addition to these answers, there were also those who answered that how to prevent pregnancy was by eating young pineapples or smoking. The picture above clearly shows a non-ideal situation, where parents should be the main source of information about sexuality for adolescents, in fact friends are the main source of information, while it is understandable that the information obtained from friends may not be true. or only half right. In addition, the values and ethics about sexuality that should be conveyed by parents are not conveyed.

The result is a shift in values, from old values based on eastern culture and religious teachings that are still embraced by parents to values commonly called "new values" that become role models for today's children, a value that comes from culture. West. This in turn will be a factor that adds to the large gap between generations and the higher rates of deviations in sexual behavior. (Danim, 2020), states that, students at high school age change completely in search of an identity in the form of sexual desire, romance and affection (Danim, 2020).
To overcome the increasing prevalence of sexual behavior deviations is to provide sex education to them, because sex education is one way to reduce or prevent unwanted negative effects, such as unwanted pregnancies, sexually transmitted diseases, depression, and feelings of guilt. The pros and cons regarding the need for sex education to be given to students only seem to occur around the definition. If sex education is defined as providing information about the intricacies of the anatomy and physiologic processes of human reproduction only coupled with pregnancy prevention techniques, then the anxiety about sex education is justified. If sex education is defined as used in this study, namely efforts to teach, raise awareness, provide information about sexual issues to children, since they understand issues related to sex, instincts, and marriage. So, when children have grown into youth and can understand the affairs of life, they already know the problems that are forbidden and permissible. In fact, being able to apply Islamic behavior as morals, habits, and will not follow lust and hedonistic ways, then with a definition like this, sex education seems very necessary to be given to our students.

2. The tendency of students' sexual behavior in high schools in Cirebon City

In addition to the things above, it is also known that some high school students in Cirebon City are dating. A total of 21 male respondents and 39 female respondents admitted to having been in a relationship. In dating, they usually still do things that are generally considered normal, such as visiting their boyfriend's house, walking together, and holding hands. None of the respondents are dating by fingering the genitals and having sex. This shows that they are still dating within reasonable limits.

Regarding the time spent dating, most of them did it in the afternoon, and only 5 respondents answered that they did it in the evening before nine o'clock. Regarding places, most of them date at tourist attractions or places to eat/cafe.

The reactions of their parents when they found out their child was dating were 
varied. Most advised, 5 respondents answered angry, 3 respondents answered they did not care, and only 1 respondent answered in favor. This is also complemented by that most of the respondents have special regulations in their families regarding dating, such as age, time, and activities allowed when dating. Sulistio Wirawan Sarwono, (2008), said that teenagers starting at the age of 11-24 years are vulnerable to actions that contain negative elements, especially in the field of sexual development and their curiosity about something (Sulistio Wirawan Sarwono, 2008).

3. Students' Perception of Sexual Deviant Behavior in SMA-SMA in Cirebon City

When asked for an opinion regarding the opinion that says that sexual behavior is deviant (homo/lesbian), all of them answered that they did not agree. The reasons put forward are various, ranging from sinful, can damage life, to some who consider the act as a disgusting thing.

Educators, especially Islamic Religious Education subject groups, are expected to be involved in serious issues surrounding the sexual behavior of students, so that parents must be more intensive in providing attention and guidance, especially regarding norms around sexuality (sex education) in a wise and prudent manner. full of empathy. Parents should realize that sex education is not only the responsibility of school educators but the most important thing is the parents themselves. Because it is parents who have the most time to meet their children and understand the most about their children's character. Parents should not taboo talking about sex to their children, instead parents should be able to choose appropriate words by considering the child's ability to understand. However, the most important thing is that the words contained in it must provide a correct description of men and women. The parents' openness and truthfulness are enough to encourage children to come back to them whenever they face uncertainty or problems about their sexual life. (Kirkendal. Lester A, 2018).

Parents also need to realize that there is a space where parents are not able to control their teenagers at all, namely when their children are outside the home or when they are outside their control zone. At times like that, only the teenager can supervise himself with all the knowledge he has received from the environment (parents, educators, reading materials, and so on).

It is a big mistake when parents think that their teenage children have no desire and interest in sex. In fact, out there is so much information about sex without knowing the right and wrong. In addition, there are also many things that arouse the lust of teenagers, such as porn posters to friends of the opposite sex in class who wear sexy clothes and tend to be aggressive. In the end, the parents were surprised by the case of a young girl who behaved shyly and tended to be disgusted when she talked about sex when her friend, who was known to be quiet and didn't act much, was pregnant. A study conducted by L.C. Jensen's study of pregnant female students showed that almost all of the respondents he studied were not interested or even disgusted by listening to sex jokes or pictures of naked men and more importantly they never read obscene books. (Sarwono, 2003).

In dealing with children, especially teenagers, there are several things that must always be remembered, namely that the soul of the teenager is a soul full of turmoil (strum und drang) and that the social environment of adolescents is also marked by rapid social changes (especially in cities that are already accessible to public facilities).and communication and transportation infrastructure) which causes confusion in cultural and religious norms. These internal and external conditions that are both volatile are what causes adolescence to be more vulnerable than other stages in the development of the human psyche.

In addition to good sex education and in accordance with its development, it is necessary to create the closest possible stable environmental conditions, especially the family environment. A family situation characterized by a harmonious husbandwife relationship will ensure that adolescents are able to go through the 
transition smoothly than if the husbandwife relationship is disrupted.

4. The Role of Schools in Overcoming the Problem of Deviant Sexual Behavior in Senior High Schools in Cirebon City

Educators, especially Islamic Religious

Education (PAI) subjects, have an important role in participating in overcoming deviant sexual behavior among their students. For this reason, educators need to place their position in various roles; as teachers, parents, consultants, and even friends. This role can be performed, both inside and outside the classroom.

The educator-student relationship has an influence on the sexual development of adolescent students, especially through the teaching and learning process in the material on the moral values of sexual behavior given through Islamic Religious Education (PAI), especially the subjects of Fiqh and Akidah Akhlak. The intensity and effectiveness of the implementation of sexual moral education will strengthen the form of students' views, attitudes, and sexual behavior based on Islamic moral values. Through classroom teaching, students will absorb an understanding of Islamic sexual moral values. Meanwhile, through the educator-student relationship outside the classroom, there will be a maturation of understanding as well as corrective and curative processes for inappropriate sexual attitudes and behavior.

In overcoming sexual behavior deviations, religious educators act as idol figures in the moral development of students. As in the development of other aspects of the soul, the process of moral development in students requires a figure of identification of moral values.

In the case of high schools throughout the city of Cirebon, especially in SMAN 1, SMAN 7 and SMAN 8 Cirebon City, the school plays several important roles in order to participate in overcoming sexual behavior deviations among their students. Some of the roles that schools play in the process of overcoming these sexual deviations include:

a. Providing Sex Education
Sex education (sex education) has not been included as a separate subject in the education curriculum in Indonesia at the elementary, middle, and high levels. However, this does not mean that sex education cannot be delivered by educators. Through the teaching and learning process in the classroom, especially Islamic Religious Education subject teachers have the opportunity to deliver this sex education. There are certain topics in Islamic Religious Education that can be used as material to convey sex education, for example the topic of baligh, purification, mandatory bathing, marriage, socializing, prohibition of adultery, and so on. Etc. Through this opportunity, the supervisor of the Islamic Religious Education subject group is able to become a source of information and inspiration about healthy, good, and correct views, attitudes, and sexual behavior. Information related to the Islamic view of sexual life that is packaged and presented in an interesting way will be an inspiration for students to behave and behave.

In addition to providing formal sex education in class, high schools throughout the city of Cirebon also regularly conduct coaching by inviting an expert and holding seminars related to overcoming sexual behavior deviations. These seminars are usually held to coincide with the commemoration of Islamic holidays in the form of recitations. So far, the topics that have been conveyed include: 1) the ethics of young people in Islam, 2) reproductive health in an Islamic perspective, and 3) promiscuity and Islamic association.

The above action is a repressive effort which is a strategy carried out by PAI teachers to restrain, hinder and delay the impact of promiscuity so that it does not spread and spread even more. (Iqbal, 2014).

b. Providing Religious Moral Education

The supervisor of the Islamic Religious Education subject group is the person most responsible for religious moral education. Therefore, 
Islamic Religious Education subject teachers at SMA-SMA in Cirebon City make several efforts to instill religious morals in students so that they are able to become references in their daily behavior, including sexual behavior. This is important because there are many things that are prohibited by religion but by sex experts are considered normal things. Masturbation/masturbation, for example, is prohibited by religion (haram) because it can damage both physical and mental health. However, this is considered reasonable by sex experts. They assume that the sperm that comes out due to masturbation will soon be replaced by the protein consumed by a person so that it does not affect health. Even if you don't masturbate, the sperm must come out through a dream.

Another example is holding hands and kissing. In religious morals, these two things are prohibited and dangerous because they can cause stimuli that can drag someone into adultery. In Islamic morality, things that can lead a person to adultery are forbidden. Contrary to religious morals, sex experts comment that holding hands and kissing in courtship are harmless because they cannot damage virginity and cause pregnancy. Seeing these two contradictory views, the school, especially the teachers of Islamic religious education subjects, must be active in instilling Islamic morals in the interaction between students.

The efforts made by schools and Islamic Religious Education (PAI) subject groups in instilling religious morals are: 1) holding spiritual guidance programs every day during the 2 nd break for female students who are absent, 2) holding recitations class each class. The implementation is outside school hours, according to the agreement of students and their respective homeroom teachers. Although outside school hours, this class recitation must be held at least once per year, 3) hold a taklim assembly in commemoration of Islamic holidays, and 4) hold a flash boarding school every Ramadan.

c. Controlling Discipline

Controlling discipline is not an easy job. Discipline of learning, attending class, how to dress is a classic problem faced by every educator. For this reason, schools have an important role in instilling a disciplined spirit inspired by religious teachings. Religion teaches humans to be disciplined. Religion is also capable of making people disciplined. For example, when praying a person will not reduce the rak'ah even though no one is looking. This kind of discipline can only be instilled by religion. Therefore, schools should be very good at looking for the basics of discipline in religion to be applied in the daily lives of students. In turn, this discipline attitude can also be grown in the association and sexual behavior of students.

In tackling the misuse of technology, the school implements regulations so that students keep their devices during school hours in the places provided. Before school hours end, student devices can only be accessed if they get permission from subject teachers who need devices to support the learning process. Sanctions such as confiscation and several other sanctions are imposed for students who violate. For students who are caught accessing or storing content not It is also appropriate that strict sanctions have been prepared from blocking devices from internet access in schools to confiscation of devices.

d. Become a Consultant and Friend

Adolescence is a tentative period, namely a period of uncertainty. They feel mature because physically they are perfect like adults, but mentally they are still children. Therefore, at this time teenagers often have problems, including their sexual life. Adolescent sexual life experiences various problems that are not easily solved by themselves. But teenagers do not like to involve other people to solve their problems except with people who are considered close friends, can be 
trusted, and feel they have the same experience. (Haditono, 2019). In this case, religious subject educators can act as consultants who act as friends.

Through educator-student interactions outside the classroom, the role of educators as consultants in the sexual life of students can be carried out, either through counseling activities or through educator-student relationships on other occasions. In this case, educators must be able to act as close friends who are ready to accept complaints and various stories with an objective attitude. The relationship between educators and students outside the teaching and learning process in the classroom can provide opportunities for educators to act as preventers, correctors, and curators of deviant sexual behavior from students.

In that context, the schools in high schools throughout the city of Cirebon made several efforts, including the following:

1) Conducting direct or indirect consultation guidance for all students spearheaded by BP/BK, Student WAKA and homeroom teacher.

2) All teachers are open to students in the hope that students will be open about the problems they face.

3) Stakeholders, teachers and education staff always maintain closeness with students to monitor problems that arise among their students.

According to (Muchith, 2017), PAI teachers are required professionally to master all fields of PAI science, such as explaining the primacy of prayer, meaning PAI teachers must know psychological science about psychology, must master health sciences because prayer consists of movements which of course will Bring health to body and soul (Muchith, 2017).

\section{CONCLUSION}

This study aims to describe the purpose of this study to describe sex education in Islamic religious learning to prevent and overcome deviant behavior in high schools throughout the city of Cirebon. The results of this study indicate that in general, students in SMA-SMA in Cirebon City do not all have sufficient knowledge about sexuality. In addition, many of the students still consider it taboo to talk about sexual education. It is a separate task for educators to explain the concept of sexual education. Do not let students actually get information from sources that cannot be accounted for. In overcoming sexual behavior deviations among students in high schools throughout the city of Cirebon, schools play an important role. Some of the roles that schools play in the process of overcoming sexual deviance include (1) providing sex education, (2) providing religious moral education, (3) controlling discipline, (4) becoming consultants and friends for their students.

\section{REFERENCES}

Danim, Sudarwan. (2020). Perkembangan peserta didik.Google Scholer

Iqbal, Muh. (2014). Peranan Guru Pendidikan Agama Islam dalam Menanggulangi Perilaku Menyimpang Peserta didik SMA Negeri 1 Pomalaa Kabupaten Kolaka. Universitas Islam Negeri Alauddin Makassar. Google Scholer

Madani, Yusuf. (2003). Pendidikan seks untuk anak dalam Islam. Jakarta: Pustaka Zahra. Google Scholer

Muchith, M. Saekan. (2017). Guru PAI yang Profesional. Quality, 4(2), 200-217. Google Scholer

Sarwono, Sarlito Wirawan. (2003). Pergeseran Norma Perilaku Seksual Kaum Remaja (Changes in sexual behavior norms among adolescent). Jakarta: CV. Rajawali and the Indonesian Planned Parenthood Association. Google Scholer

Wuryani, Sri Esti. (2008). Pendidikan Seks Keluarga. Jakarta: Indeks. Google Scholer 


\section{Copyright holder:}

Sri Maryati, Muhibbinsyah, Aan Hasanah, Erihadiana (2021)

First publication right:

Journal of Social Science

This article is licensed under:

(c) $\underset{\mathrm{BY}}{\mathrm{BY}} \mathrm{SA}$ 